\title{
Facies architecture of heterolithic tidal deposits: the Holocene Holland Tidal Basin
}

\author{
M.E. Donselaar ${ }^{*} \&$ C.R. Geel ${ }^{1}$ \\ Department of Geotechnology, Delft University, of Technology, P.0. Box 5048, 2600 GA Delft, the Netherlands. \\ 1 Present address: TN0 Built Environment and Geosciences, Geological Survey of the Netherlands, P.0. Box 80015, 3508 TA Utrecht, \\ the Netherlands. \\ * Corresponding author. Email: m.e.donselaar@tudelft.nl
}

Manuscript received: October 2007; accepted: December 2007

\begin{abstract}
The size, shape and spatial position of lithofacies types (or facies architecture) in a tidal estuarine basin are complex and therefore difficult to model. The tidal currents in the basin concentrate sand-sized sediment in a branching pattern of tidal channels and fringing tidal flats. Away from the sandy tidal flats the sediment gradually changes to mud-dominated heterolithic deposits and clay. In this paper the facies analysis of a tidal estuarine basin, the Holocene Holland Tidal Basin (HHTB) is presented based on core data and Cone Penetration Tests (CPT). Four lithofacies associations are recognized: (1) tidal channel sand, (2) sand-dominated heterolithic inter-tidal flat, (3) mud-dominated heterolithic inter-channel, and (4) fresh-water peat. The high data density allowed for the construction of a detailed facies architecture model in which the size, shape and spatial position of the tidal estuarine facies elements were established. The results can be used to improve the reservoir modelling in highly heterogeneous estuarine reservoir settings.
\end{abstract}

Keywords: Facies architecture modelling, tidal estuary, heterolithic deposits

\section{Introduction}

The sediment distribution in a tidal estuarine basin is conditioned by the tidal surge that moves in and out the basin with each tidal cycle. The tidal energy is dispersed in the branching network of tidal channels and creeks. The high-energy tidal currents transport the coarsest, sand-sized sediment as megaripples on the tidal channel floor. Sandy heterolithic sediment is deposited on inter-tidal flats that fringe the tidal channel and on inter-tidal point bars in channel bends. Away from the tidal channels the tidal current energy dissipates and mud-dominated heterolithic and clay sedimentation prevail in sub-tidal inter-channel areas. The resulting spatial distribution of sediment types, or facies architecture, is very complex and therefore difficult to model and predict. An adequate modelling of the spatial arrangement of the sand-prone parts is especially relevant in hydrocarbon reservoirs in this sedimentary environment, such as, e.g., the Tilje Formation (Pliensbachian, Early
Jurassic) reservoirs in the Haltenbanken area offshore midNorway (Dreyer, 1992; Donselaar \& Geel, 2003; Martinius et al., 2005), the Cook Formation (Early Jurassic) in the Oseberg Field, northern North Sea, offshore Norway (Donselaar et al., 2006), and The Lower Graben Sand (Late Jurassic) in the F3FB Field, offshore the Netherlands.

In the present paper a detailed facies model is constructed of tidal estuarine deposits in the Holocene Holland Tidal Basin (HHTB) in the west of the Netherlands (Fig. 1) with the aim to assess the spatial distribution and connectivity of the sandprone sediments in the basin. The data density allowed for the construction of a highly data-constrained facies architecture model that comprises size and shape data, directional trends and spatial relationships of the lithofacies associations in the tidal estuary. The studied Holocene tidal estuarine sediments belong to the Beemster Deposits (Fig. 2; Westerhoff et al., 1987; Beets et al., 1996), now called the Wormer Member of the Naaldwijk Formation (Weerts et al, 2000). The deposits are in 


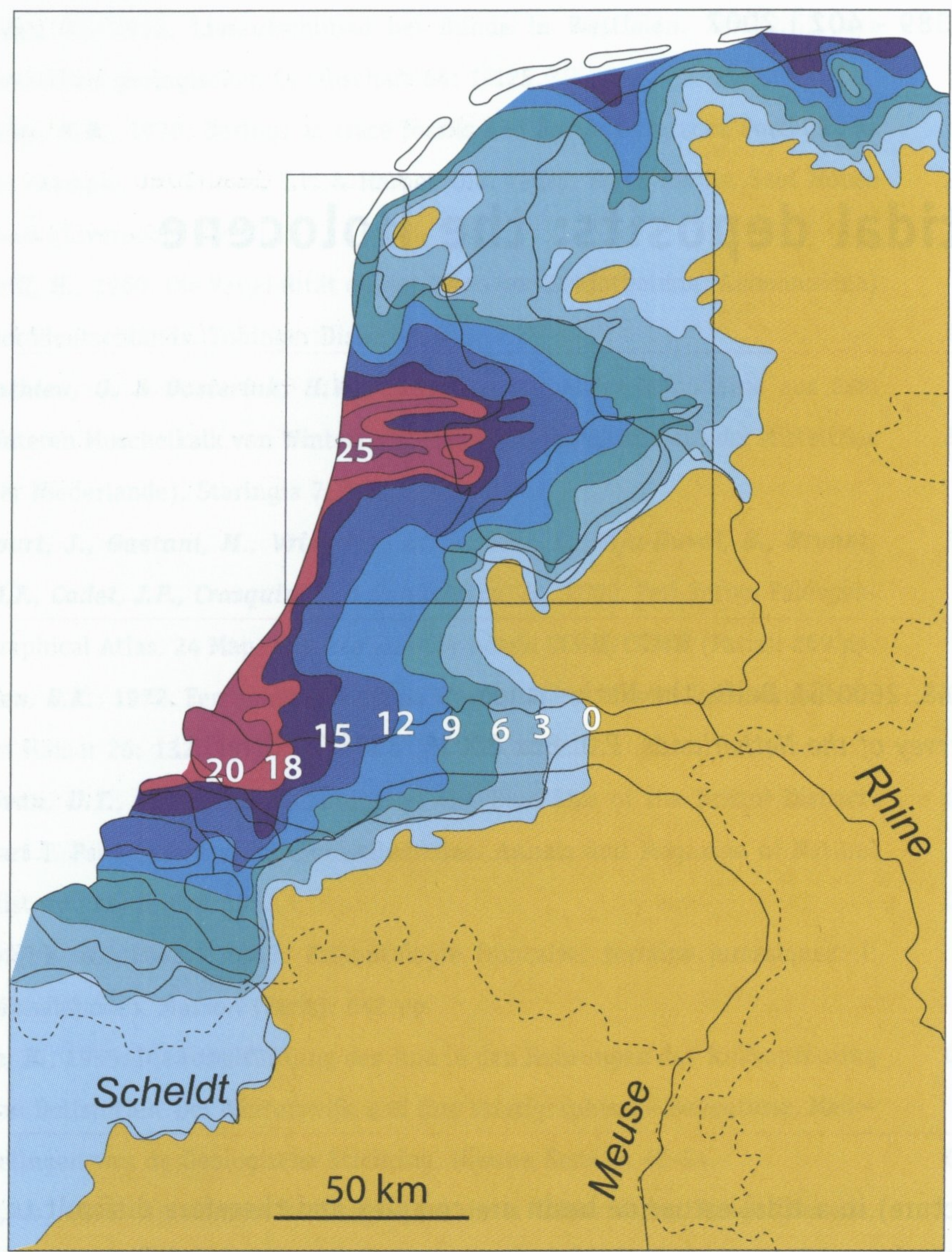

Fig. 1. Top of the Late Weichselian surface of the Netherlands shows the depth of the valley incision during the glacio-eustatic lowstand. Southern valley at the confluence of the Rhine and Meuse rivers; northern valley at the confluence of the Eem and Overijsselse Vecht rivers. Depth contours in metres. Box: area of Fig. 6. After Zagwijn (1986).

the shallow subsurface (down to $30 \mathrm{~m}$ depth) in a tectonically undisturbed area. The area is densely perforated with Cone Penetration Tests (CPT) and cored boreholes. The general geological setting of the basin is well known from numerous publications (De Mulder \& Bosch, 1982; Westerhoff et al., 1987; Van der Spek, 1994; Beets et al., 1996; Beets \& Van der Spek, 2000; Beets et al., 2003).

\section{Data and Methods}

This study is based on the analysis and correlation of subsurface data sets from two sources: (a) lacquer peels of undisturbed cores, and (b) logs of Cone Penetration Tests (CPT). Lithofacies descriptions were made of cores from the wells 14C-53 Burgervlotbrug, 19C-819 Heemskerk, 19D-271 Klaterbuurt, 19D-272 West Graftdijk, and 19G-369 Beemster (see Fig. 3 for well locations). 344 CPT logs were digitized and processed for the correlation panels. CPT are used to identify soil types in an unconsolidated environment. A cone at the end of a series of rods is pushed into the ground at a constant rate, while continuous measurements are made of (a) the resistance to penetration of the cone (b) the friction of the outer surface of a
Fig. 2. Holocene stratigraphy column of the HHTB. Modified from Beets et al. (2003).

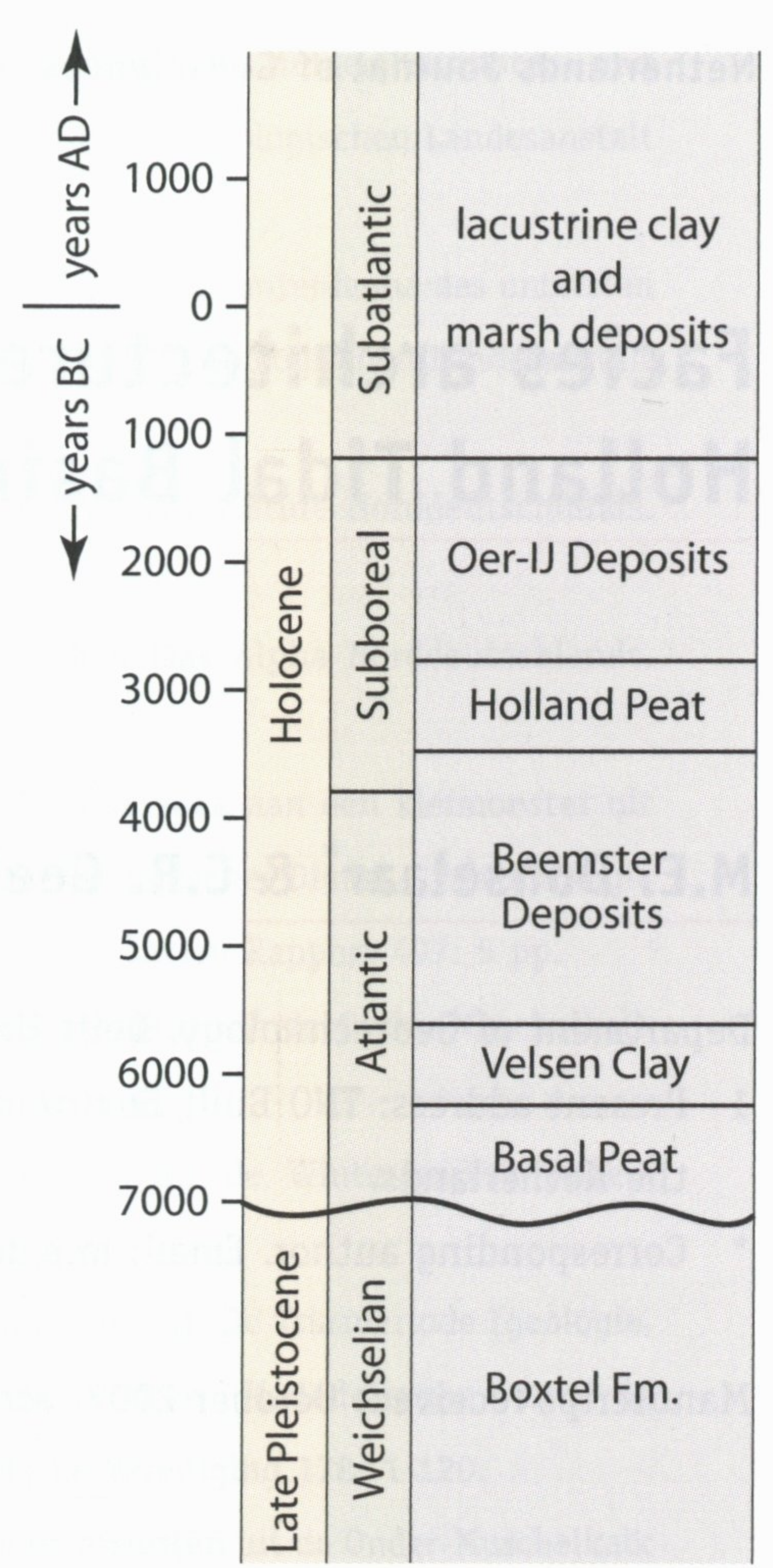

sleeve surrounding the rod, and (c) the pore pressure (Fig. 4). Cone resistance is a measure of grain size, and sleeve friction (degree of stickiness) is related to clay content (Lunne et al. 1997). Combination of the measurements can be converted to lithology. The resolution of the logs is in $\mathrm{cm}$.

CPT logs are routinely taken prior to the construction of roads and buildings in the soft soil of the Netherlands, and are usually closely spaced with distances of $100-300 \mathrm{~m}$. The commercial software package CPT-Pro was used to convert the CPT logs to lithological logs. Cores were described from boreholes nearby CPT locations. The core data were used to verify CPT-derived lithology logs. The lithofacies characteristics were then linked to the various sub-environments of the tidal basin. The CPT correlation panels yielded size and shape data, directional trends and spatial relationships of the sedimentary genetic types in the tidal basin. These data were used to build a facies architecture model for the tidal basin fill in an 11 by $14 \mathrm{~km}$ area of the basin (Fig. 3).

\section{Geological Framework}

During the Weichselian glacio-eustatic lowstand (Late Pleistocene) the westward-draining rivers in the western part of the Netherlands responded to the base-level drop by erosion of the early Late Pleistocene deposits (Fig. 1). River valleys incised deeply into the marine Eem Formation (early Late Pleistocene) and formed two east-west trending valleys: the Rhine-Meuse Valley in the south and the Eem-Vecht Valley in the north. During the subsequent Holocene glacio-eustatic sea-level rise the valleys were flooded. The Rhine and Meuse rivers supplied sufficient sediment to fill the southern valley 


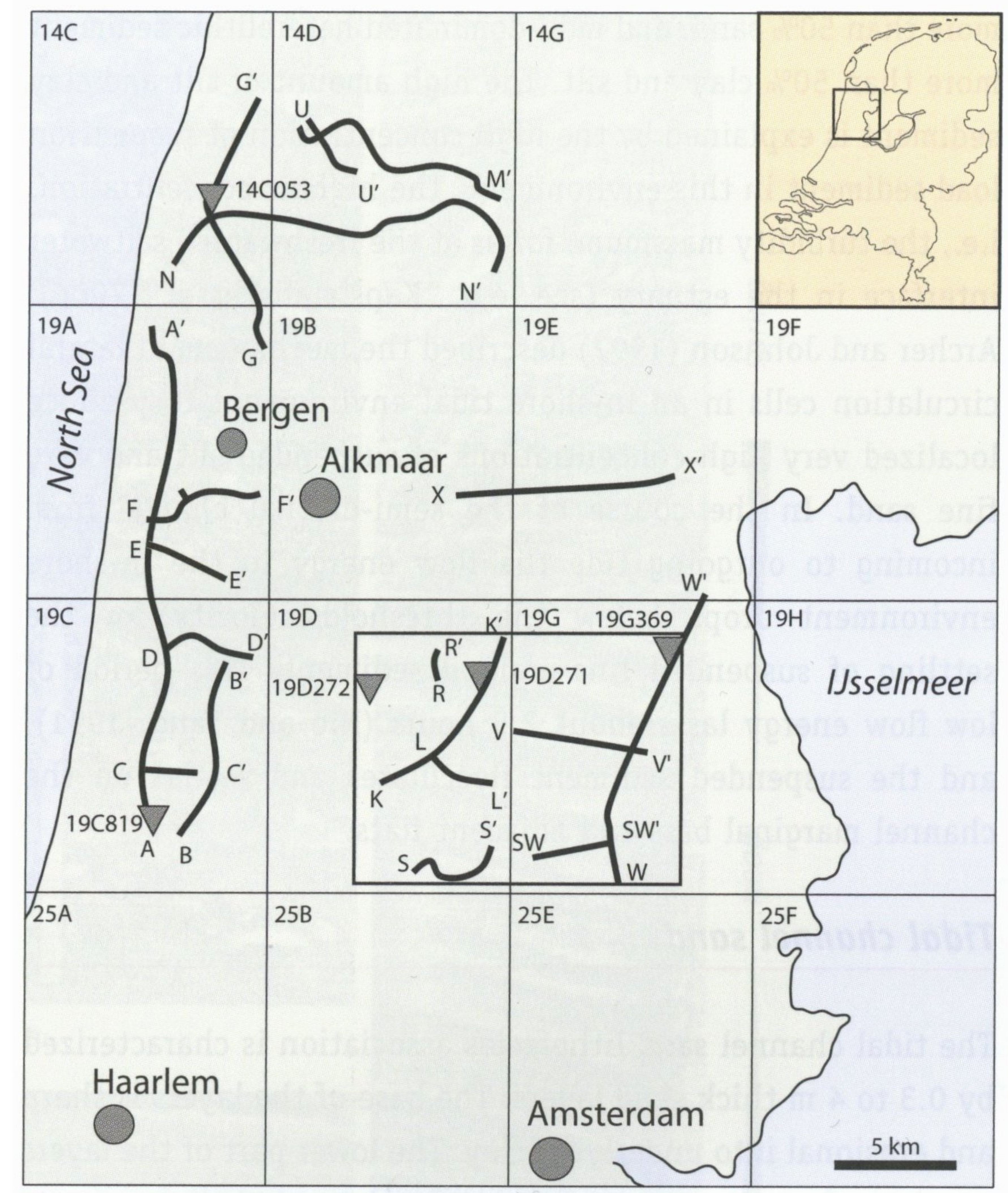

Fig. 3. Location map of CPT correlation lines ( $A-A^{\prime}, B-B^{\prime}$, etc.) and cores (triangles) used in this study. Box in 19D-19G indicates the area of the lithofacies architecture model.

with fluvial sediments (Beets et al., 1996). The northern valley was drained by small local rivers and their sediment supply did not keep pace with the sea-level rise. Hence, this valley converted to an estuarine basin landward of a northsouth elongate barrier island chain (Van der Spek, 1994; Beets $\&$ Van der Spek, 2000; Beets et al., 2003). The entrance to the HHTB was formed by tidal inlets in the thalweg of the incised fluvial valleys. The entrance positions remained fixed during the entire basin formation and infill history. The tidal inlets branched out eastward in an intricate pattern of tidal channels and shoals bordered by inter-tidal flats (Cleveringa \& 0ost,
1999). Sub-tidal lagoons developed in the inter-channel area, and on the landward side the basin was fringed by a narrow belt of freshwater marshes (Beets et al., 2003). The tidal signature of the HHTB deposits was, a.o., described by Ente (1971) and Roep (1991). The estuarine basin had a micro-tidal regime (Roep \& van Regteren Altena, 1988).

Flooding started around 8000 BP (Beets \& Van der Spek, 2000). The initial rate of Holocene sea-level rise $(8000-6000$ BP) was $1 \mathrm{~cm} / \mathrm{yr}$ (Fig. 5). The rate of sea-level rise slowed down to $0.6 \mathrm{~cm} / \mathrm{yr}$ after $6000 \mathrm{BP}$, and to $0.3 \mathrm{~cm} / \mathrm{yr}$ between 5000 and $3900 \mathrm{BP}$. After this time the rate of sea-level rise further decreased to $0.15 \mathrm{~cm} / \mathrm{yr}$ (between 3900 and $1400 \mathrm{BP}$ ) and to $0.05 \mathrm{~cm} / \mathrm{yr}$ from $1400 \mathrm{BP}$ onwards (Jelgersma, 1979; Van de Plassche, 1982). In the initial phase of sea-level rise (early transgressive systems tract, or TST) the rate of accommodation increase was high and exceeded the sediment supply. This resulted in the aggradational stacking of the various in-shore tidal facies, while the basin gradually expanded and reached its largest extension of $2800 \mathrm{~km}^{2}$ around 5500 BP (Fig. 6). After the deceleration of the rate of sea-level rise (late TST) the sediment supply was in balance with the accommodation increase and resulted in the infill of the basin. As a consequence of the slower accommodation increase, the tidal channels migrated laterally over the adjacent tidal flats and sub-tidal inter-channel areas. Basin infill was completed during HST (after $3000 \mathrm{BP}$ ). Maximum thickness of the Holocene succession in the study area is $35 \mathrm{~m}$.

The sediment was derived from the reworked Pleistocene basement during flooding, and from tide-induced cross-shore transport from the North Sea (Beets \& Van der Spek, 2000; Beets et al., 2003). The Holocene sedimentary fill reflects the gradual flooding of the basin: a marsh deposit, the Basal Peat, formed on top of the Pleistocene truncation surface and is covered with fine-grained, brackish water clay, the Velsen Clay. It is overlain by a sequence of sand, thinly bedded heterolithic and clay deposits, the Beemster Deposits that formed in a tidal estuarine environment (Westerhoff et al., 1987). These deposits are covered by peat and clay deposits of the Holland

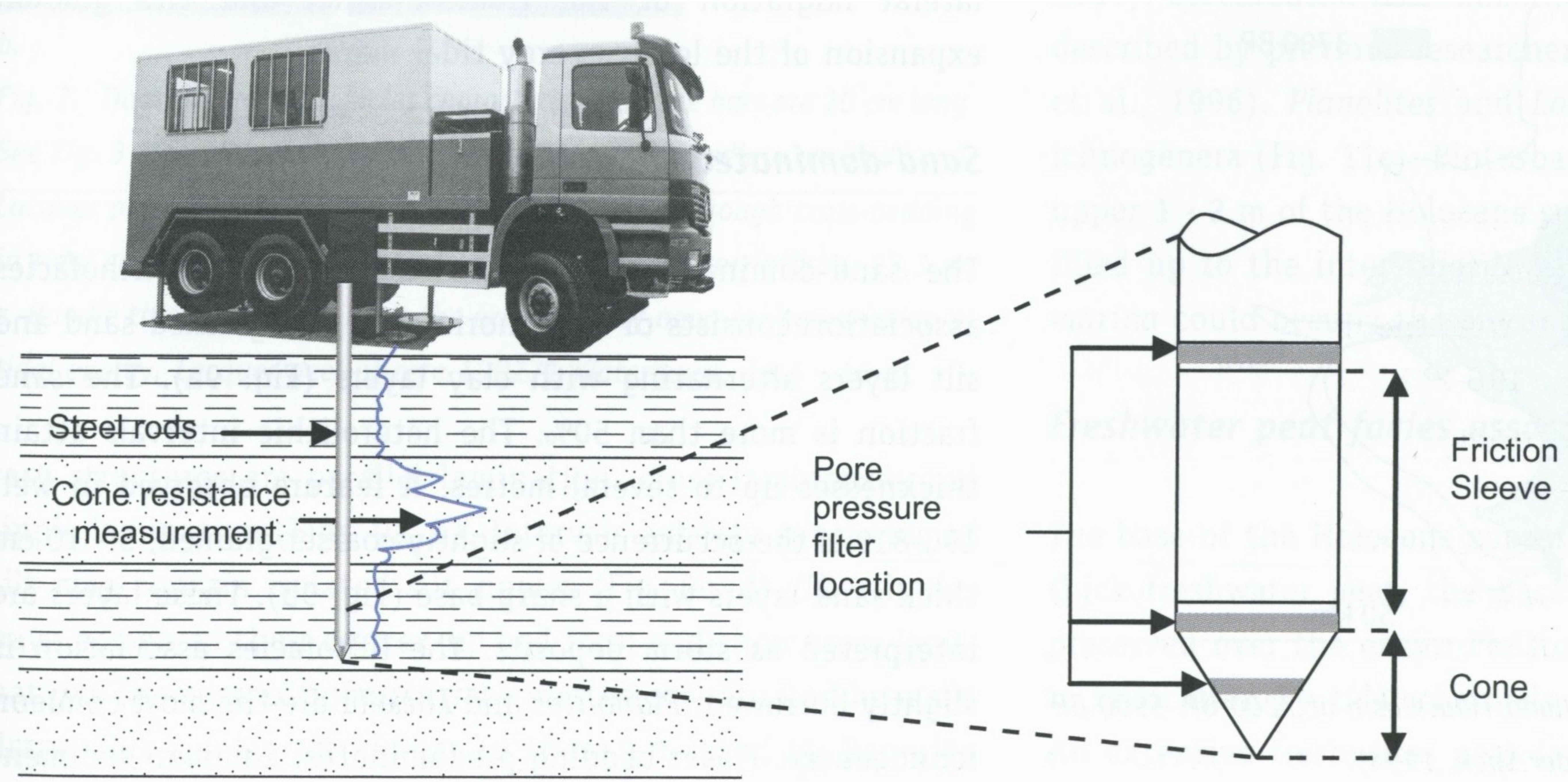

Fig. 4. Cone Penetration Test. A cone on the end of a series of rods is pushed into the ground at a constant rate, while continuous or intermittent measurements are made of the resistance to penetration of the cone. Additional measurements are made of the friction of the outer surface of a sleeve and of the pore pressure. 


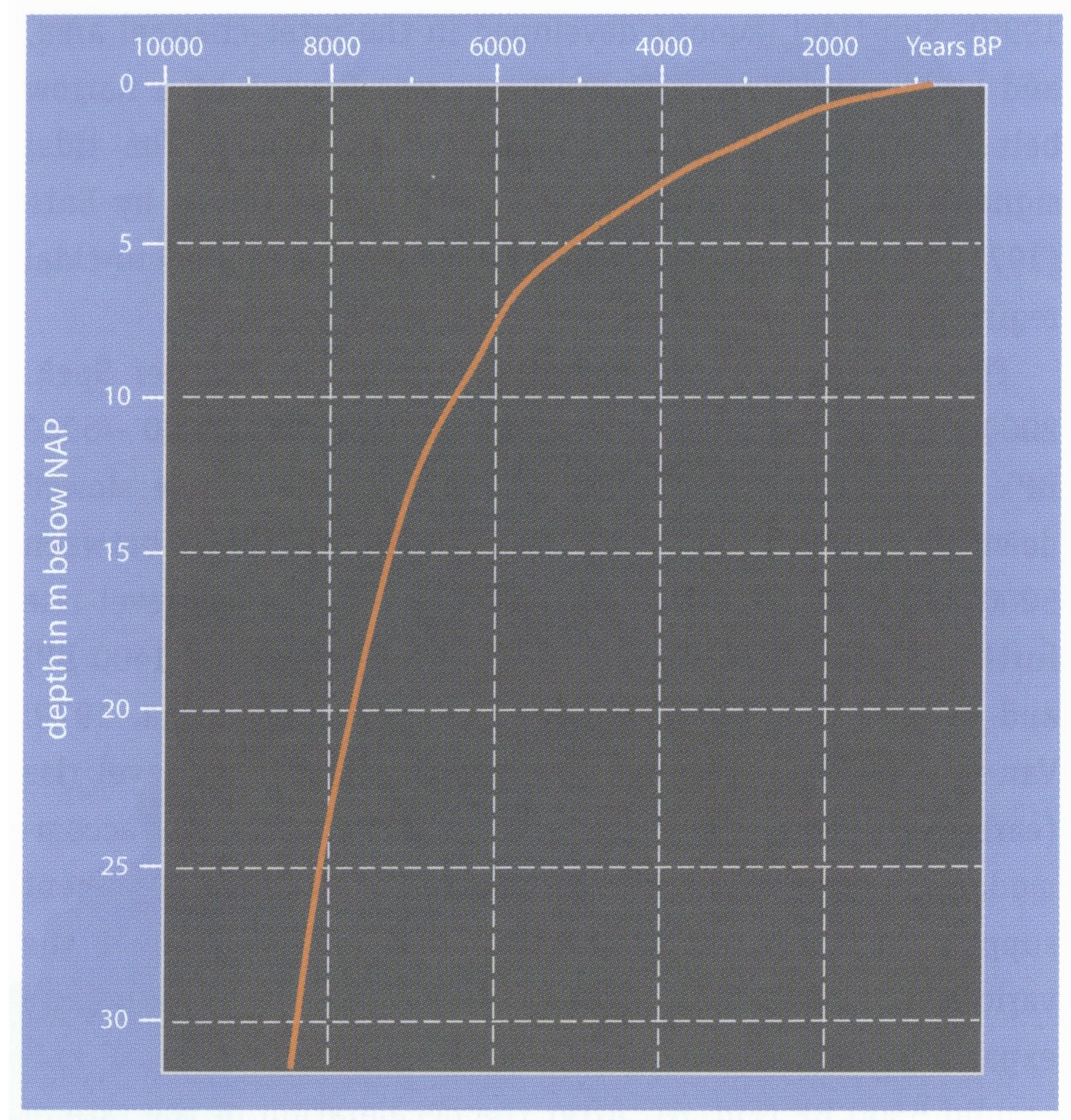

Fig. 5. Holocene sea-level curve of the western Netherlands. After Jelgersma, 1979.

Peat and 0er-IJ Deposits respectively, which formed as the tidal estuary gradually filled (Beets et al., 2003). The last stage of infill consists of freshwater lake and marsh deposits.

\section{Lithofacies associations}

The Beemster Deposits in the HHTB comprise four lithofacies associations: (1) tidal channel sand, (2) sand-dominated heterolithic inter-tidal flat, (3) mud-dominated heterolithic inter-channel, and (4) freshwater peat. Heterolithic sediment consists of a succession of thinly bedded ( $\mathrm{mm}$ to $\mathrm{cm}$ scale) sand, silt and clay layers. Sand-dominated heterolithic sediment has

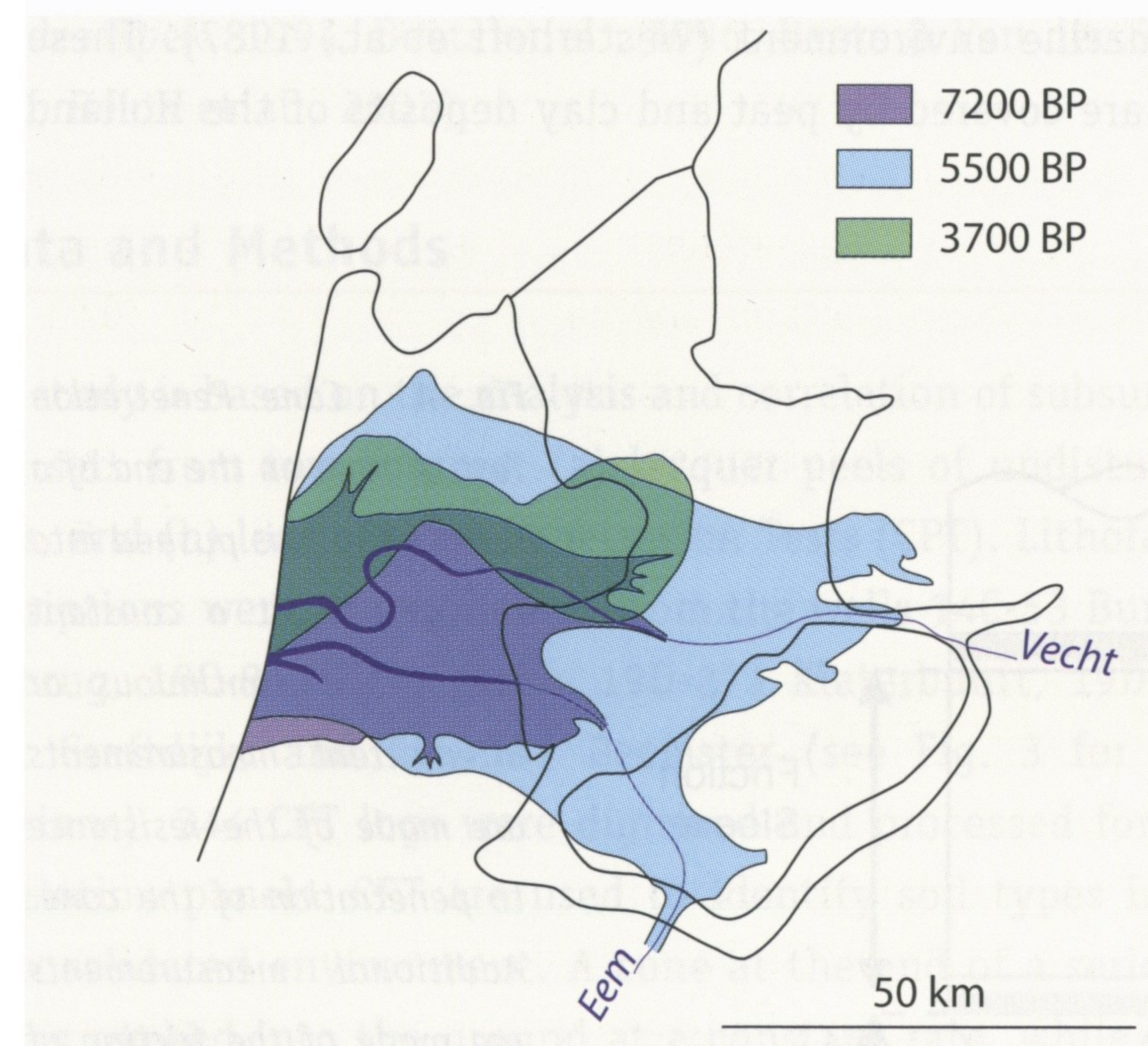

Fig. 6. Extent of the Holocene Holland Tidal Basin at 7200 BP, 5500 BP and 3700 BP (modified from Van der Spek, 1994). more than $50 \%$ sand, and mud-dominated heterolithic sediment more than $50 \%$ clay and silt. The high amount of silt and clay sediment is explained by the high concentration of suspension load sediment in this environment. The highest concentration, i.e., the turbidity maximum, forms at the freshwater - saltwater interface in the estuary (see, e.g., Kapsimalis et al., 2004). Archer and Johnson (1997) described the mechanism of lateral circulation cells in an in-shore tidal environment to produce localized very high concentrations of suspended silt and very fine sand. In the course of the semi-diurnal change from incoming to outgoing tide the flow energy in the in-shore environment drops below the threshold velocity for the settling of suspended fine-grained sediment. This period of low flow energy lasts about 2.5 hours (Nio and Yang, 1991), and the suspended sediment flocculates and settles on the channel marginal bars and adjacent flats.

\section{Tidal channel sand}

The tidal channel sand lithofacies association is characterized by 0.3 to $4 \mathrm{~m}$ thick sand layers. The base of the layers is sharp and erosional into underlying clay. The lower part of the layers consists of medium-grained sand with lags of shell fragments and clay pebbles (Fig. 7a). The grain size decreases upward to fine-grained sand; shell fragments and mud pebbles are absent. Bioturbation grade is low and increases towards the top of the sand layers. An exception are the strongly burrowed tidal channel sand layers in the lower part of well 19G-369 Beemster (Fig. 8, interval $12.2-14.8 \mathrm{~m}$ ). Plant roots are a common feature in the upper part of the sand layers. Internal scouring surfaces occur and are marked by a sharp grain-size increase and the reappearance of shell fragments. Trough cross-bedding and planar lamination are present in the lower half of the channel fill (Fig. 7b). Cross lamination is typical in the upper part. Double mud drapes and bundle thickness variations in cross-bedded sets evidence the in-shore tidal environment of deposition (Fig. 7c; Visser, 1980; Nio \& Yang, 1991). The upward increase of bioturbation and plant roots is explained by the lateral migration of the tidal channel and the gradual expansion of the lower energy tidal marsh.

\section{Sand-dominated heterolithic inter-tidal flat}

The sand-dominated heterolithic inter-tidal flat lithofacies association consists of thin, horizontal fine-grained sand and silt layers alternating with clay layers (Fig. 9a). The sand fraction is more than $50 \%$. The heterolithic intervals attain thicknesses up to several metres. A feature observed in well $19 \mathrm{C}-819$ is the occurrence of slightly coarser grained, $5-10 \mathrm{~cm}$ thick sand layers with a sharp base (Fig. 9b). These layers are interpreted as storm deposits. The lithofacies association is slightly burrowed. Planolites and Lockeia are the most common ichnogenera. Flaser bedding predominates. Common sedimen- 


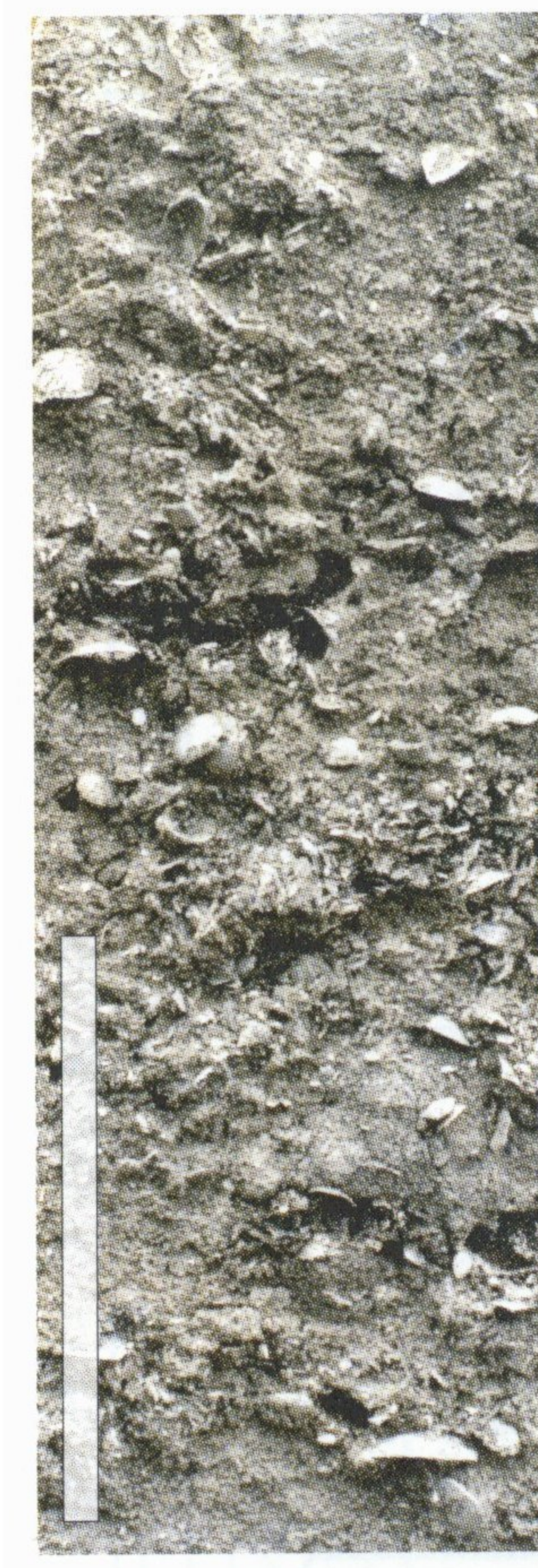

a.

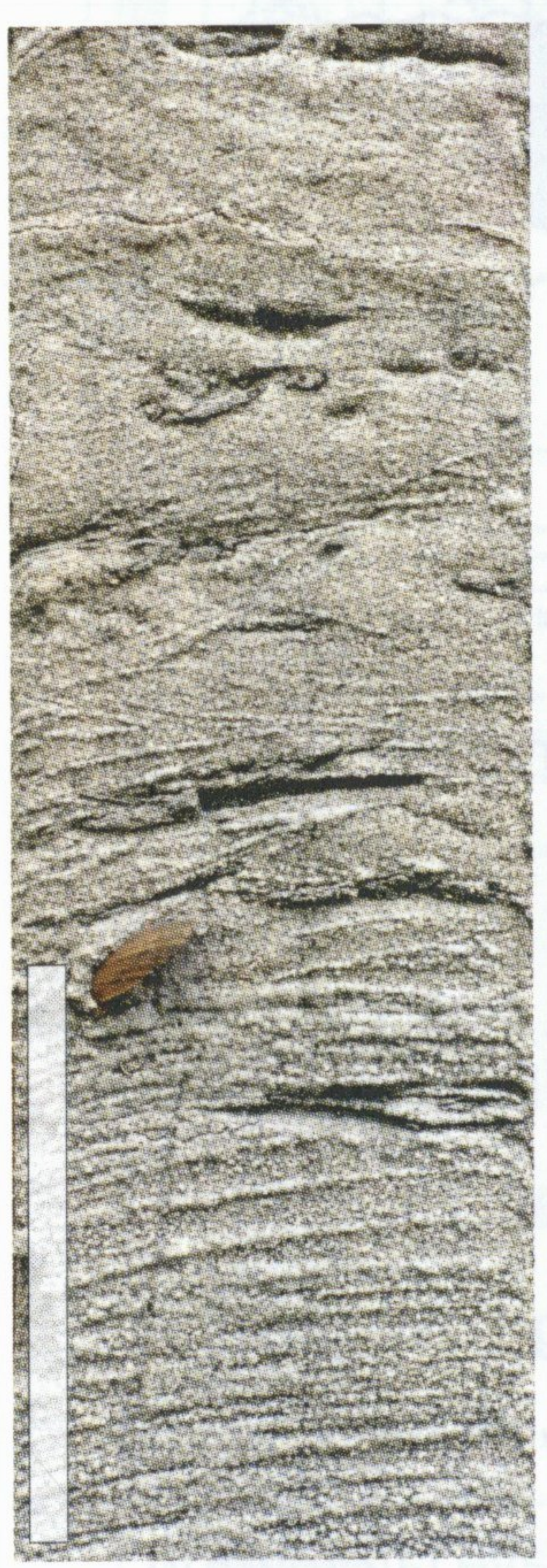

b.

Fig. 7. Tidal channel lithofacies characteristics. Scale bars are $10 \mathrm{~cm}$ long. See Fig. 3 for well locations. a. Shell fragments in medium grained sand. Lacquer peel of core 196369 Beemster, $12.1 \mathrm{~m}$; b. Trough cross-bedding in tidal channel fill. Lacquer peel of core $14 C 53$ Burgervlotbrug, 13.3 m; c. Bundle thickness variation is the expression of neap-spring variation in tidal energy. Lacquer peel of core 190271 Klaterbuurt, 15.5 - 16 m.

tary structures are parallel lamination, cross lamination and ripple lamination (Figs. 9a, b). Intervals entirely consisting of silt may contain isolated silt ripples (Fig. 9c, d). The ripples have preserved their convex-up bed form and show cross lamination. The convex upper surface may be accentuated by a silt drape. Silt ripples are similar to those produced by Banerjee
(1977) in flume experiments. These experiments were performed to study the vertical sequence of sedimentary structures in silt from a decelerating suspension current. Banerjee (1977) used variable rates of deceleration, and the current deceleration was from $46 \mathrm{~cm} / \mathrm{s}$ to $9 \mathrm{~cm} / \mathrm{s}$. Moderate deceleration (3 - 5 hours) produced $2-3 \mathrm{~cm}$ thick silt layers consisting of a basal graded interval, followed by a parallel laminated interval, then a weakly-developed ripple laminated interval and finally a thin silt drape that covers the ripple, and accentuates the ripple shape. The ripple train development was incomplete. The experiments with a moderate deceleration and a settling time of $2 \mathrm{~h} 40 \mathrm{~min}$. produced sedimentary structures comparable with those in the silt intervals in the sand-dominated heterolithic inter-tidal flat and the mud-dominated heterolithic interchannel lithofacies associations. The time slot for settling of suspension load in the flume experiments coincides well with that of the settling time in a semi-diurnal tidal environment (2.5 hours approximately, Nio \& Yang, 1991).

\section{Mud-dominated heterolithic inter-channel}

The mud-dominated heterolithic inter-channel lithofacies association forms the bulk of the sediment fill in the HHTB (about $70 \%$ ). It consists of silt and very fine sand laminae in a clay matrix, with less than $50 \%$ sand plus silt (Fig. 10). Thickness of the sand and silt laminae is $1-30 \mathrm{~mm}$; with an average of $5 \mathrm{~mm}$. Common sedimentary features include parallel lamination and isolated ripples encased in clay (Fig. 11a). Synaeresis cracks frequently occur (Fig. 11b). The synaeresis cracks are $10-15$ $\mathrm{mm}$ long, sub-vertical cracks with an irregular zigzag shape and a narrow upper and lower termination. In the lacquer peels they stand out as small silt ridges embedded in clay and are thus easily distinguished from cylindrical burrows. They are described as sub-aqueous shrinkage cracks that form as the volume of clay minerals decreases due to salinity changes (Collinson and Thompson, 1982). Salinity changes occur on a daily basis in a tidal estuary and the structures are therefore common in this environment (see, e.g., Martinius et al., 2005). Bioturbation is common, although not as abundant as described by previous researchers (Van der Spek, 1994; Beets et al., 1996). Planolites and Lockeia are the most abundant ichnogenera (Fig. 11c). Bioturbation is most prominent in the upper 1 - $2 \mathrm{~m}$ of the Holocene succession, when the basin had filled up to the inter-tidal level and burrowers like Arenicola marina could occupy the environment (Van der Spek, 1994).

\section{Freshwater peat facies association}

The base of the Holocene succession consists of a $15-40 \mathrm{~cm}$ thick freshwater peat, the Basal Peat. The peat layer is not preserved over the entire Pleistocene-Holocene boundary due to truncation by tidal channels (e.g., well Beemster, Fig. 8). An extensive freshwater peat layer, the Holland Peat, occurs 


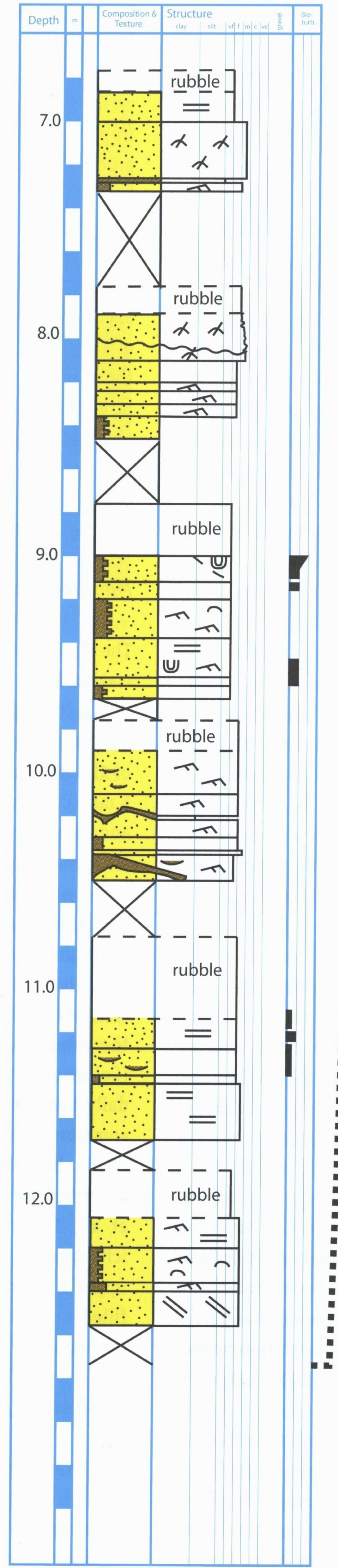

Fig. 8. Core description logs of the wells. a. Burge vlotbrug; b. Beemster; and c. Klaterbuurt. See Fig. 3 for the well locations.

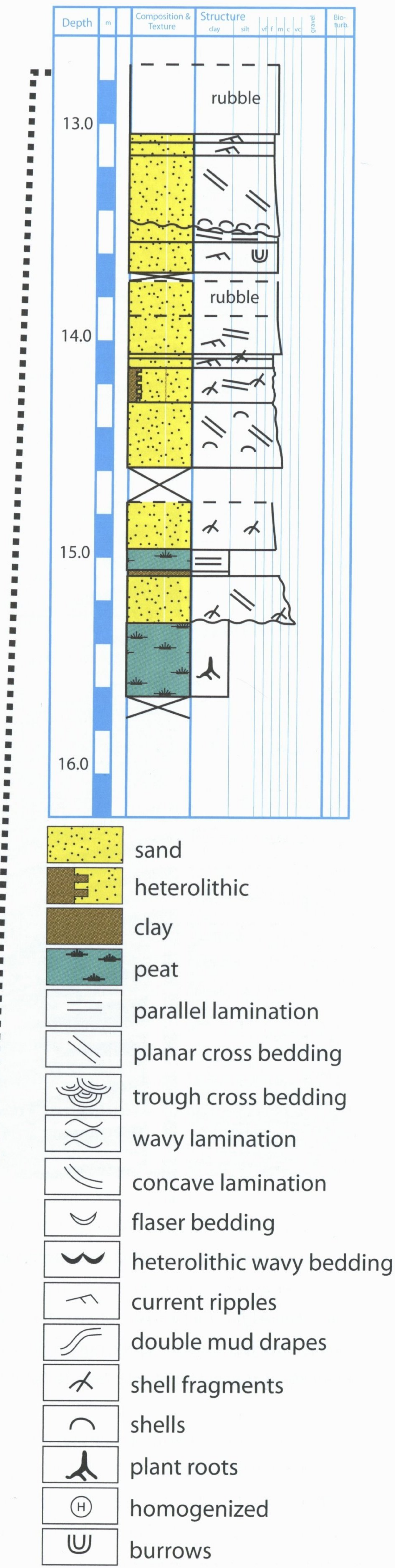

a. Burgervlotbrug. 

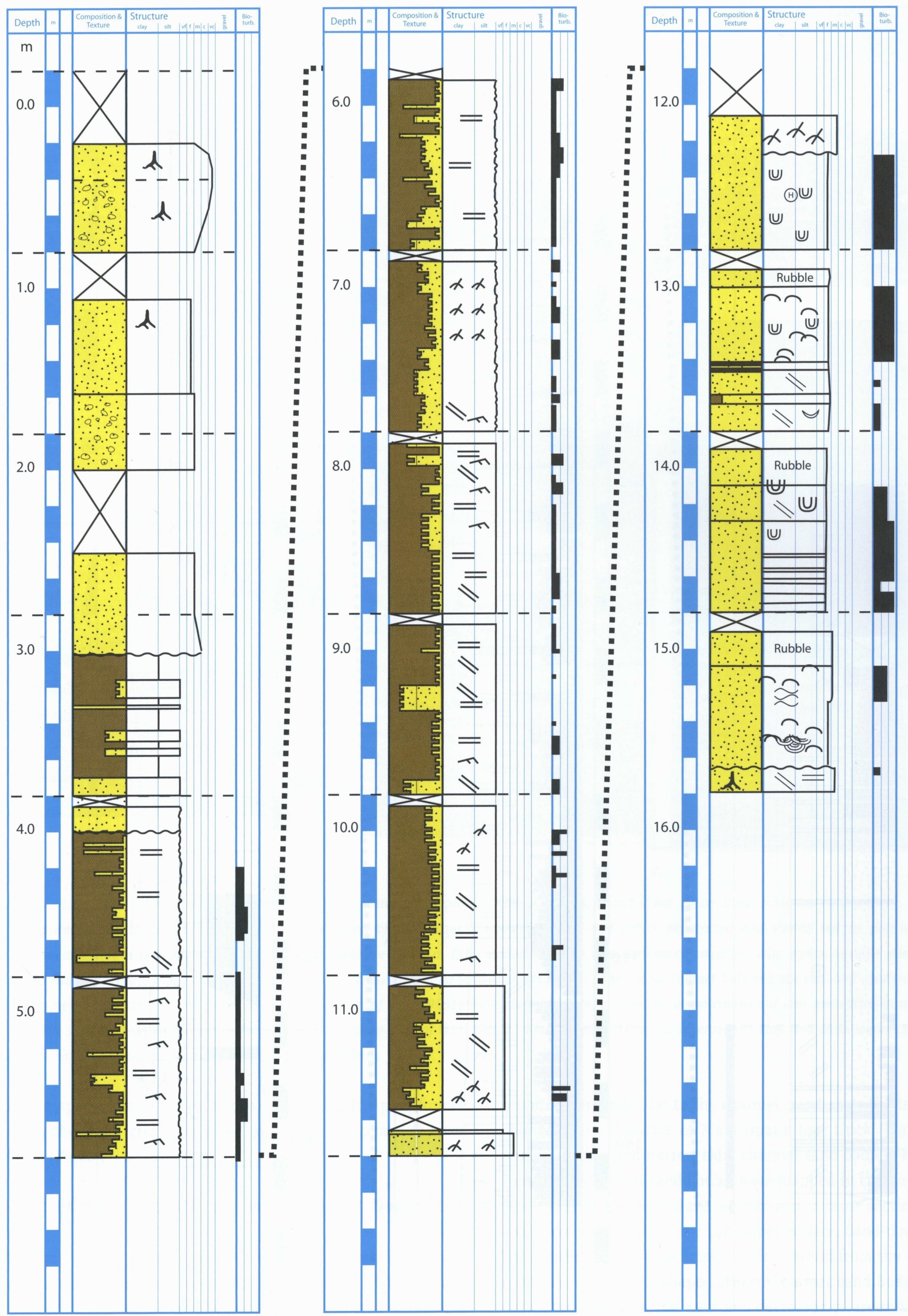

b. Beemster. 

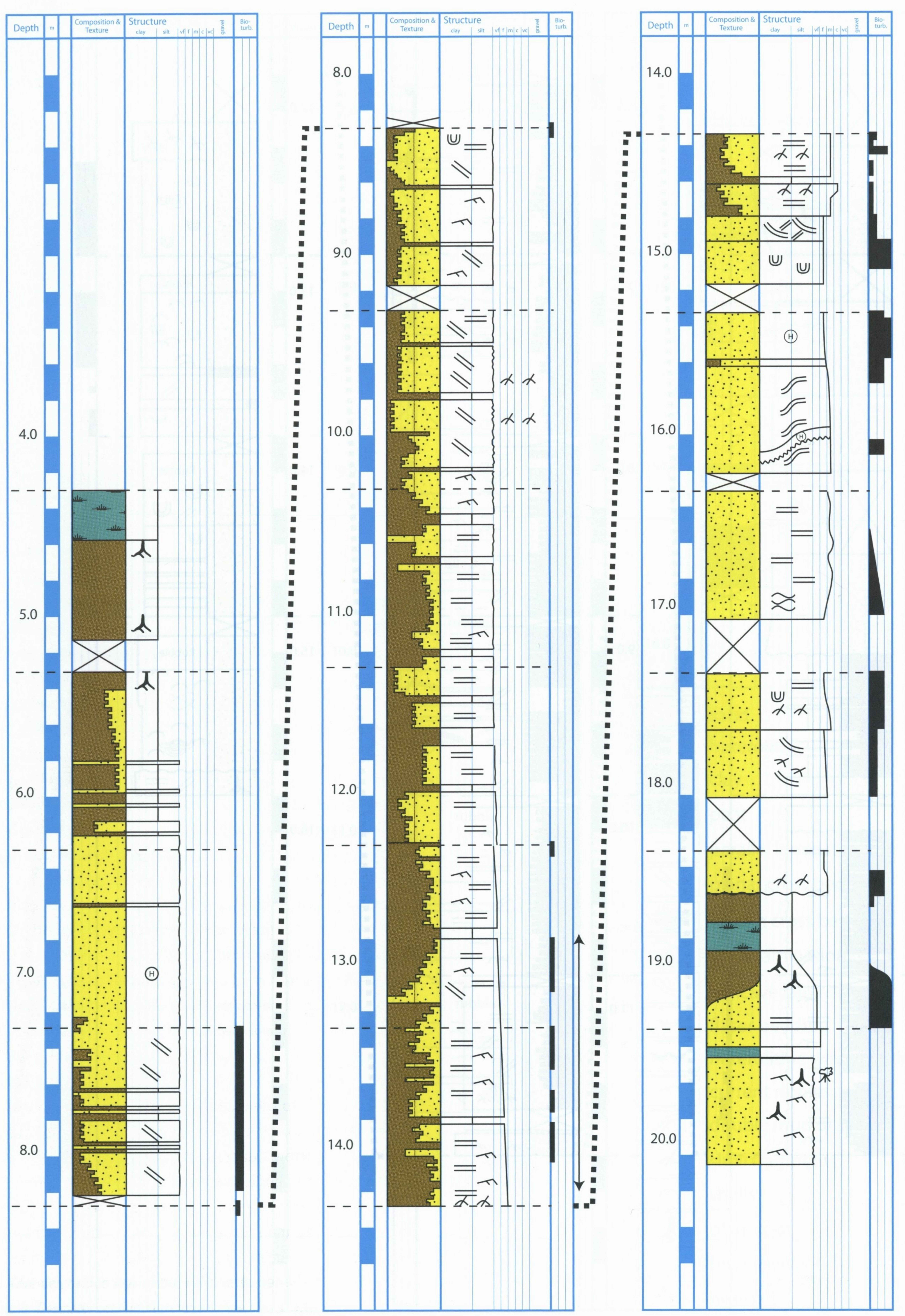

c. Klaterbuurt. 


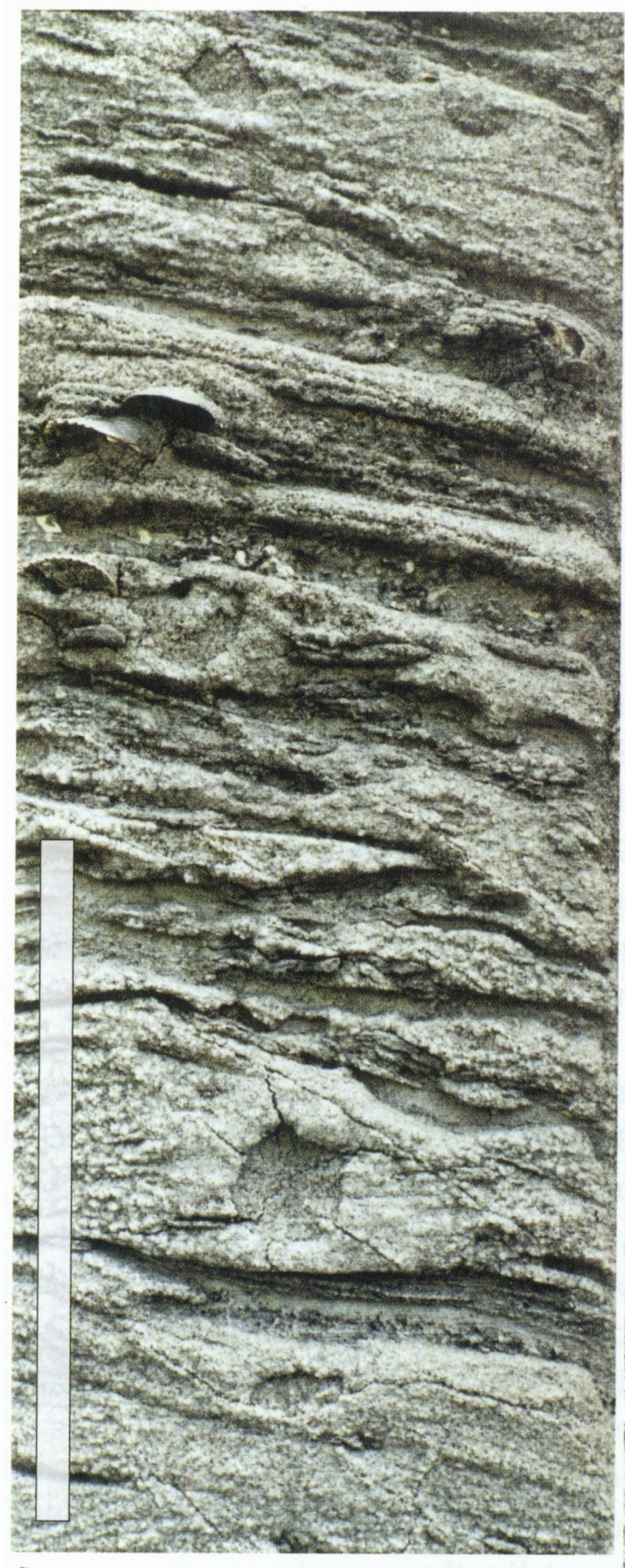

a.

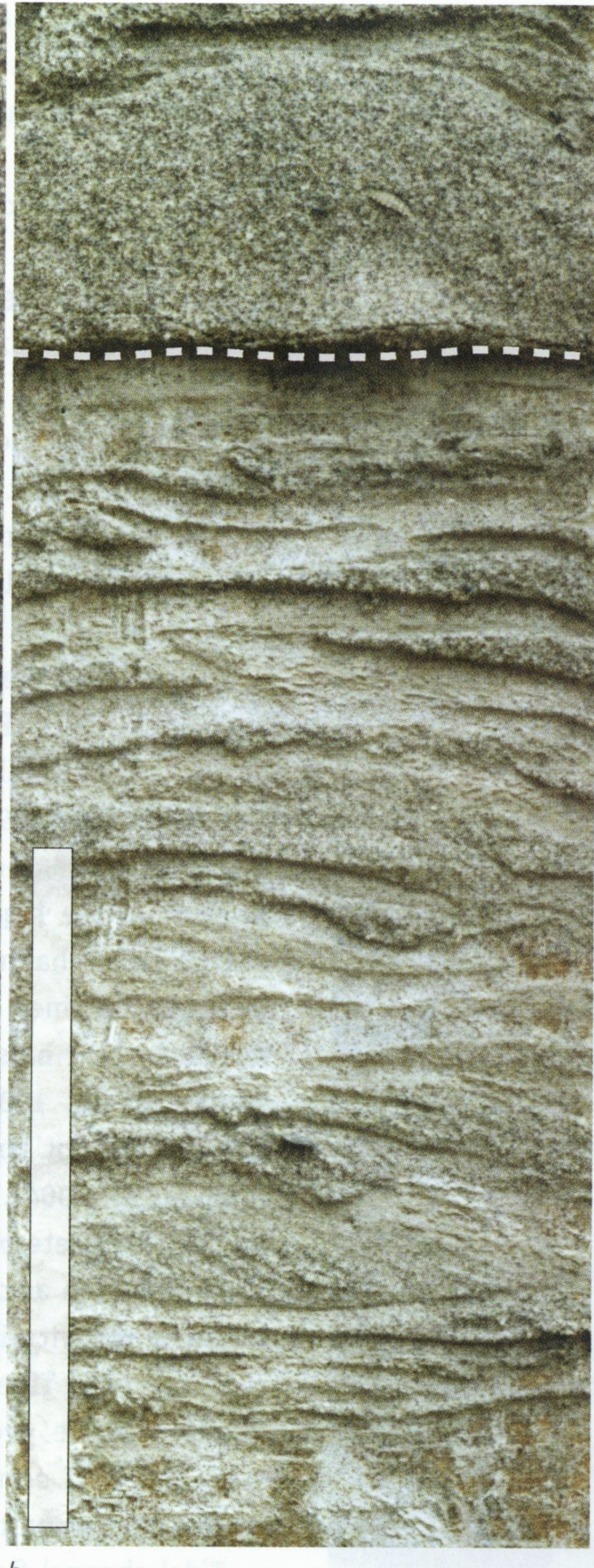

b.

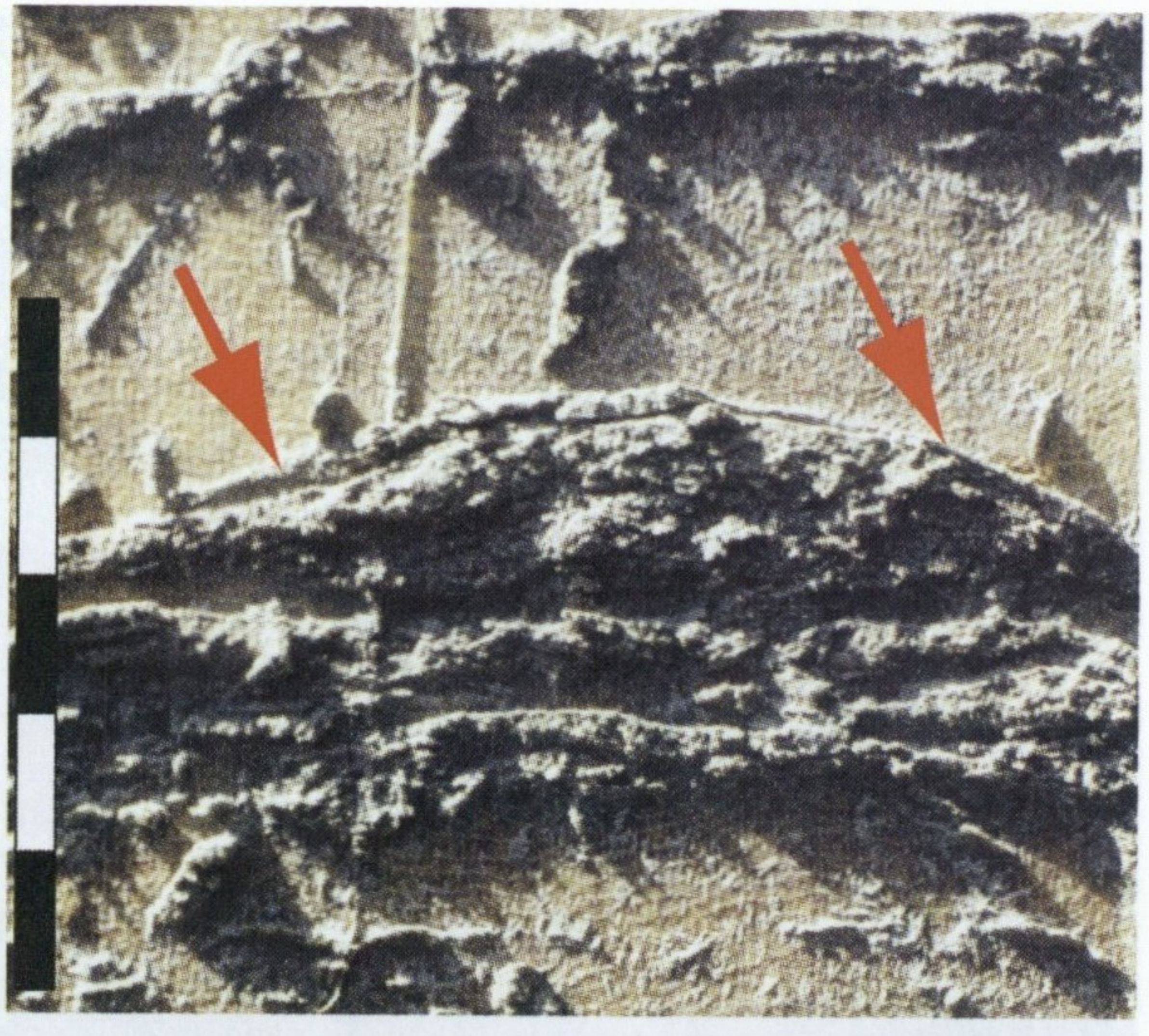

c.

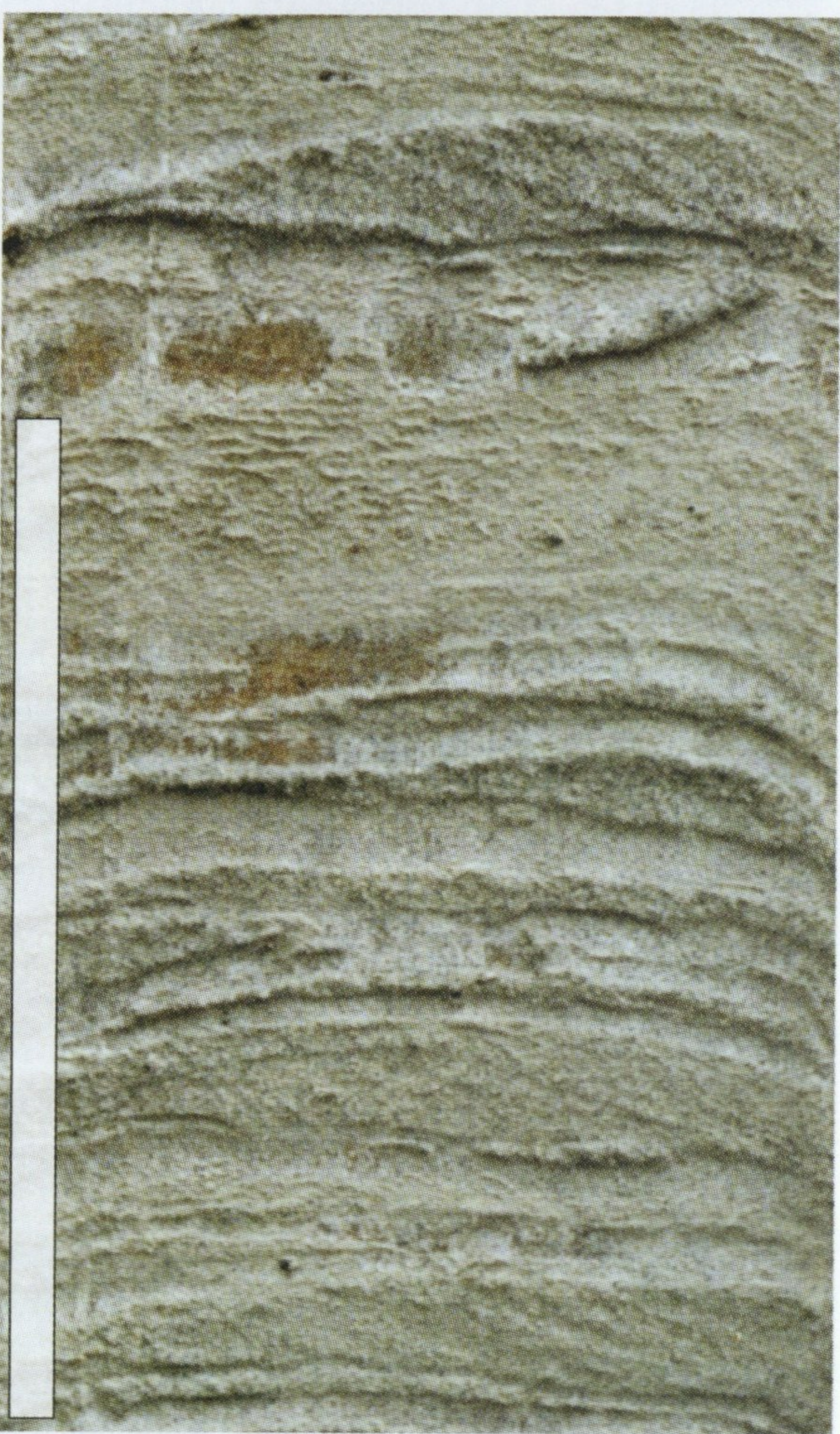

$d$.

Fig. 9. Lithofacies characteristics of sand-dominated heterolithic deposits. Scale bars in A, B and D are $10 \mathrm{~cm}$ long; scale bar in $C$ is $5 \mathrm{~cm}$. Relief in the lacquer peels is caused by differential penetration of the lacquer: permeable sand and silt is penetrated and stands out as positive relief, impermeable clay is not peeled off and is seen as negative relief. a. Interbedded very-fine cross-laminated sand and clay layers. Lacquer peel of core $14 \mathrm{C53}$ Burgervlotbrug, $9.4 \mathrm{~m}$; b. Interbedded clay and cross-laminated lenticular silt layers. Sharp basal contact between the clay and overlying, 5-cmthick fine-grained sand layer (dotted line). Lacquer peel of core 196819 Heemskerk, $15.5 \mathrm{~m}$; c. Isolated plano-convex silt lens embedded in clay. Note the thin silt drape on the upper surface (arrows). Lacquer peel of core 190271 Klaterbuurt - $14 \mathrm{~m} ; \mathrm{d}$. Interbedded clay and cross-laminated planoconvex silt lenses. Lacquer peel of core 196819 Heemskerk, $13.6 \mathrm{~m}$.

in the upper part of the Holocene succession. The peat formed when the basin gradually silted up in the last phase of basin infill (Beets et al., 2003).

\section{Facies Architecture of the Beemster Deposits}

CPT correlation panels indicate that the Beemster Deposits consist of an intricate network of juxtaposed and vertically stacked tidal channel sand bodies embedded in mud-dominated sub-tidal heterolithic and clay sediment (Figs 12,13). Panels oriented perpendicular to the channel trend show the landward change over a distance of $7 \mathrm{~km}$ from a few, thick (Fig. 12) to numerous thin and narrow tidal channel sand bodies (Fig. 13). Four generations of sand bodies were mapped in this area (Figs $12,13)$. The sand bodies are lens-shaped in cross section, with a concave lower surface and flat upper surface. Sand-dominated heterolithic tidal flat sediment bodies extend from the channel sand bodies as sheet-shaped wings. Channel sand body thickness is up to $6 \mathrm{~m}$ in the west and decreases to around $3-4 \mathrm{~m}$ in the east. 


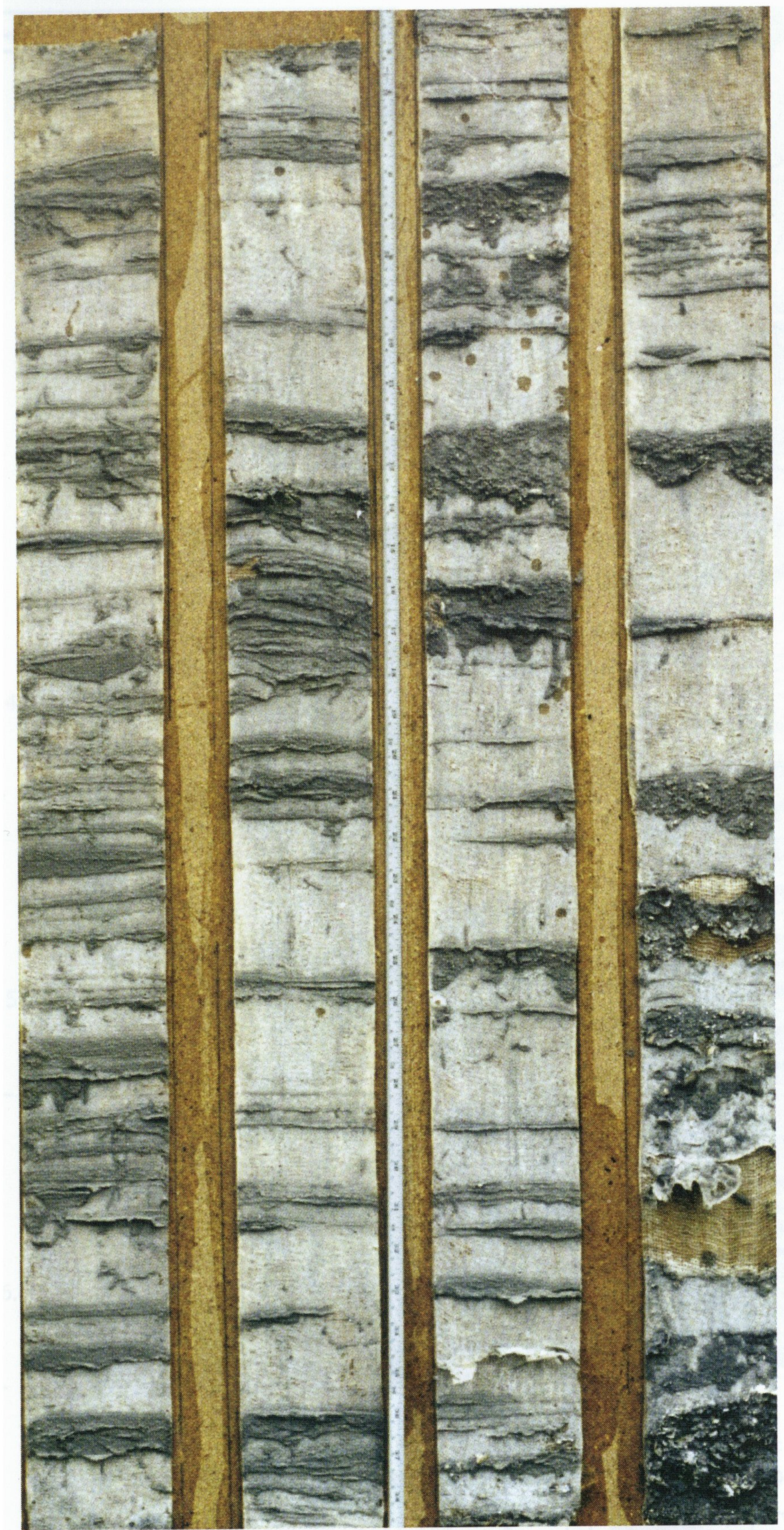

Fig. 10. Mud-dominated heterolithic lithofacies. Thin silt layers (darker colour) embedded in clay (light colour). Lacquer peel of core 136369 Beemster, $7.8-11.8 \mathrm{~m}$. Core sticks are $1 \mathrm{~m}$ long.

Plan view reconstruction based on the correlation of $\mathrm{CPT}$ panels illustrates that the Beemster Deposits tidal channel sand bodies have an east-west elongate, slightly sinuous ribbon shape (Fig. 14). The individual channel sand bodies are continuous over the length of the model area, i.e., their minimum length is $14 \mathrm{~km}$. The tidal channel sand bodies bifurcate to the east. Width and thickness decrease upon bifurcation. Width values have an uncertainty because of the spacing of CPT log locations. Channel width attains a maximum of $1.3 \mathrm{~km}$ in the west part of the area and decreases to an average of $400 \mathrm{~m}$ in the east.
The sand-dominated heterolithic tidal flat deposits fringe the tidal channel sands along their entire length. The thickness of the tidal flat deposits ranges from less than a metre to several metres; the width varies from several hundred metres to more than one kilometre (Figs 12, 13).

\section{Discussion: permeability heterogeneity and sand-to-sand connectivity}

Heterolithic sedimentation is a dominant feature in tidal estuary deposits. It is the product of tidally induced variation in flow energy. Sand-prone deposits are concentrated in the tidal channels and bordering tidal flats. The sand deposits show permeability heterogeneity on various scales. Crossbedded sand on the channel floor is relatively clean and has a high permeability (Fig. 7) but low-permeable mud drapes on the foreset laminae of the cross-bed sets are a common feature (see also Nio \& Yang, 1991). Lamina-scale sand-mud couplets also occur in the sand-dominated heterolithic tidal flat (Fig. 9). Away from the high energy tidal channels, towards the low energy inter-channel area, the tidal flat mud-to-sand ratio increases. Inclined heterolithic stratification is characteristic for tidal point bars in the estuarine environment (see, e.g., Thomas et al., 1987; Choi et al., 2004). Although the mud laminae are not continuous to the bottom of the point bar (Choi et al., 2004), the tidal point bars thus show prominent permeability heterogeneity on the scale of the entire sediment body. The high amount of mud may severely hamper sand-tosand connectivity in case of a faulted tidal estuary reservoir, such as in the Tilje Formation in the Njord Field (Rivenæs et al., 2005). Here, even with small fault throws juxtaposition of sand and mud occurs and clay smearing may create sealing faults that compartmentalize the reservoir.

Tidal channel floor sand has the best reservoir potential in terms of permeability and volume. The proportion of mud laminae is low and the concentration of flow energy in the channels may partly remove previously deposited mud drapes. CPT correlation shows that the tidal channel sand in the studied succession forms continuous sediment bodies along the channel axes (Fig. 14).

Sand-to-sand connectivity perpendicular to the channel orientation depends on the width and spacing of the tidal channel sand bodies. Tidal channel width in the HHTB gradually decreases landward, whereas the number of channels increases in the same direction because of bifurcation (Fig. 14). The tidal flats extend as wings on either side of the tidal channel and thus add to the lateral connectivity potential. Although they are volumetrically not very important because of their small thickness, their width (see previous section) increases the channel width by a factor 2.6 and may thus effectively establish the lateral connectivity between channels. Geel \& Donselaar (2007) analysed various reservoir model scenarios of 


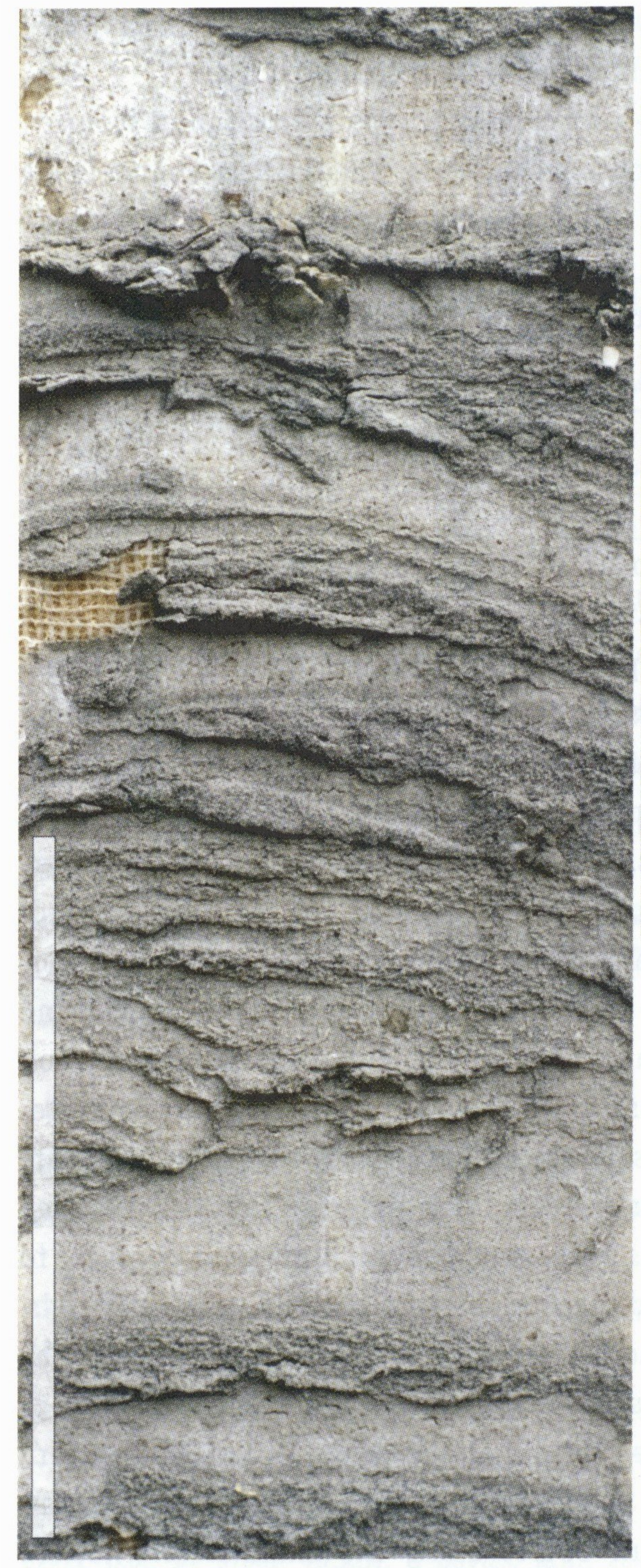

$a$.

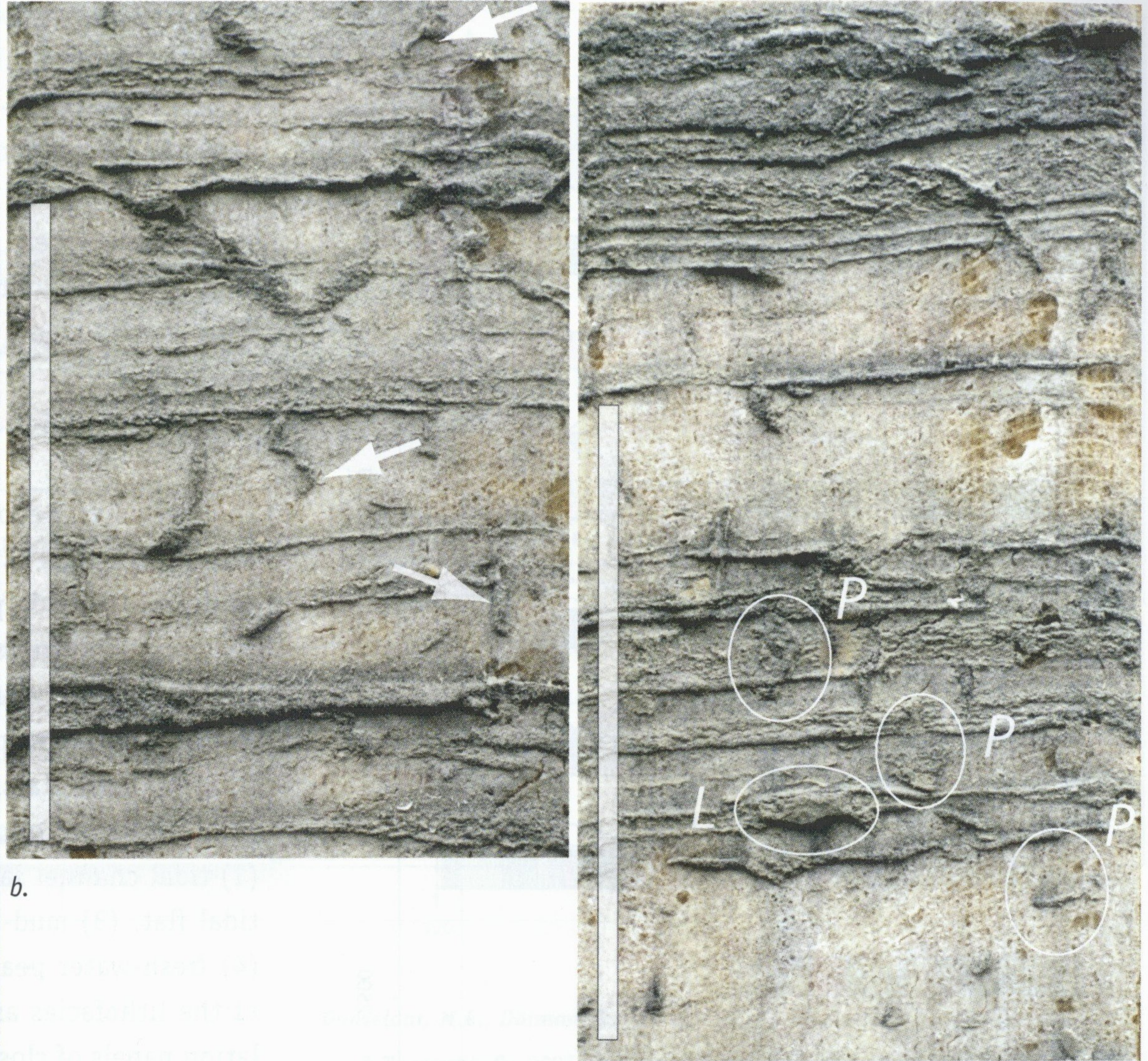

c.

Fig. 11. Mud-dominated heterolithic lithofacies. Scale bars are $10 \mathrm{~cm}$. a. Clay layers with thin, isolated silt lenses. Lacquer peel of core 136369 Beemster, $9.2 \mathrm{~m}$; b. Silt-filled synaeresis cracks (arrows) in clay layers. Lacquer peel of core $13 G 369$ Beemster, $7.3 \mathrm{~m} ; \mathrm{c}$. Planolites $(P)$ and Lockeia (L) burrows rupture the thin silt layers. Note the overall low degree of bioturbation. Lacquer peel of core $13 G 369$ Beemster, $4.4 \mathrm{~m}$.

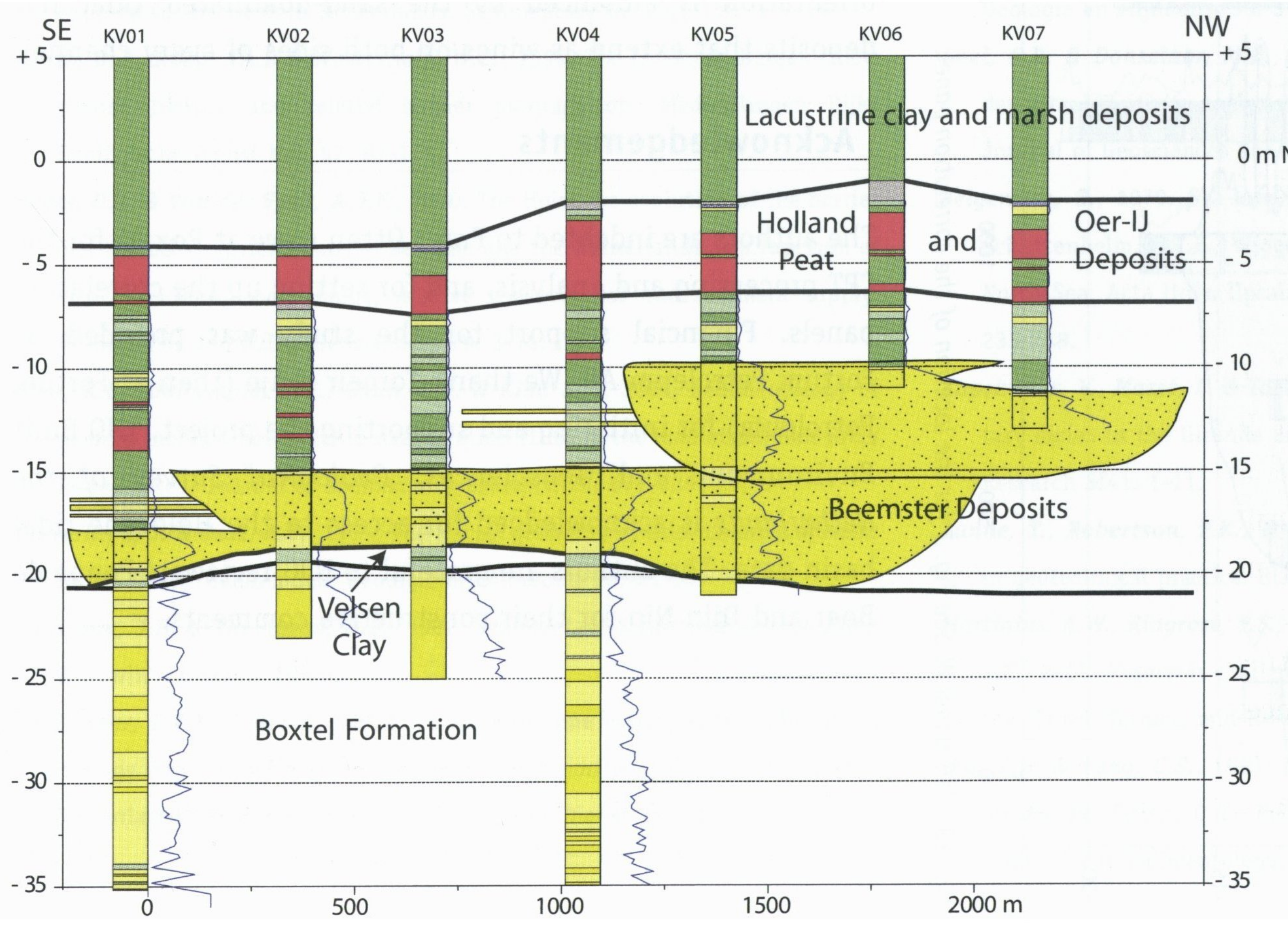

Fig. 12. CPT panel KV. See Fig. 3 for the location of the correlation panel. 


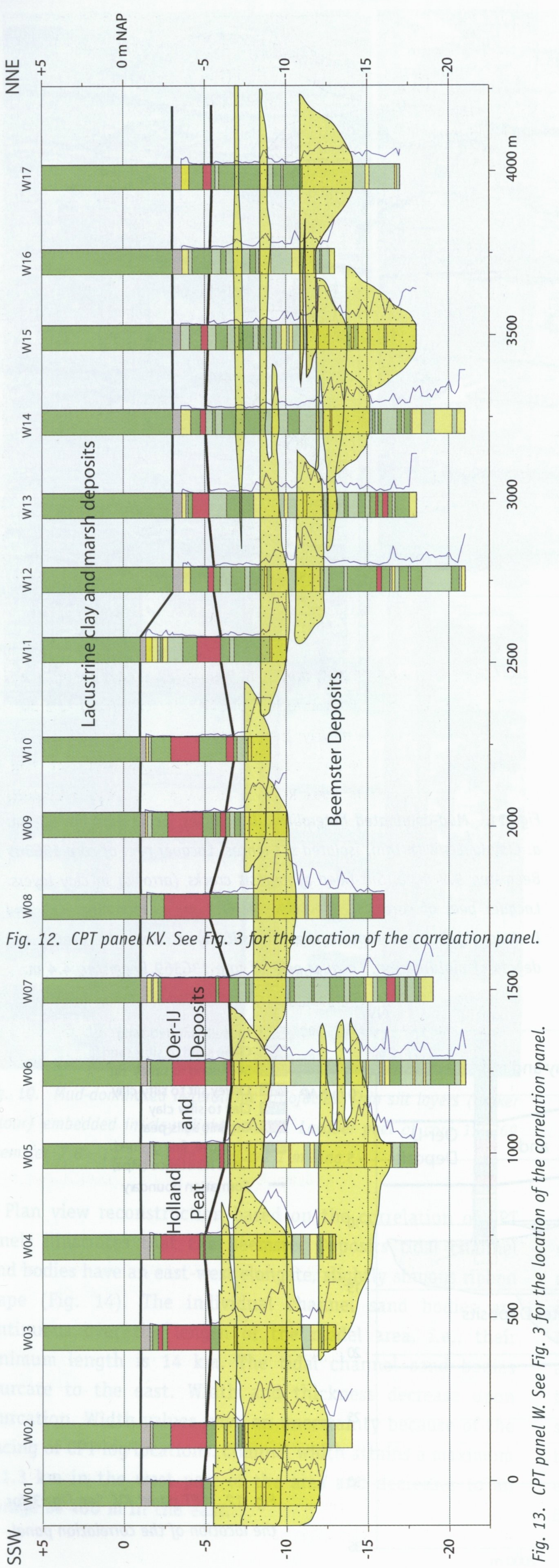

the HHTB succession and concluded that the sand-dominated tidal flat deposits improved lateral connectivity.

Vertical sand-on-sand connectivity is a function of scouring depth and accommodation increase. The deepest channels are in the west part of the model area (depth up to $6 \mathrm{~m}$ ) and are vertically stacked with an erosional sand-on-sand contact (Fig. 12). Eastward the channel thickness decreases and vertical connectivity is less obvious (Fig. 13).

\section{Conclusions}

The Beemster Deposits in the Holocene Holland Tidal Basin formed in a tidal estuarine basin. Sedimentary structures such as double mud drapes, bundle thickness variations in crossbedding, synaeresis cracks, and silt ripples are diagnostic criteria which confirm the tidal character of the deposits. Sand-prone sediment is concentrated in tidal channels and on fringing tidal flats. Grain size decreases towards the interchannel areas. Four lithofacies associations are distinguished: (1) tidal channel sand, (2) sand-dominated heterolithic intertidal flat, (3) mud-dominated heterolithic inter-channel, and (4) fresh-water peat. The size, shape and spatial distribution of the lithofacies associations were reconstructed from correlation panels of closely-spaced CPT logs. The facies architecture changes landward from a few thick and wide, vertically stacked tidal channel sands with erosional sand-on-sand contact, to numerous thin and narrow, loosely stacked tidal channels. Plan view reconstruction of the tidal channel paths in an 11 by $14 \mathrm{~km}$ model area showed the occurrence of four generations of east-west oriented tidal channels with a bifurcating pattern towards the east (landward). Tidal channel sand forms continuous sediment bodies along the channel orientation. Sand-to-sand connectivity perpendicular to the channel orientation is enhanced by the sand-dominated tidal flat deposits that extend as wings on both sides of every channel.

\section{Acknowledgements}

The authors are indebted to Frans 0tten (now at Roxar) for the CPT processing and analysis, and for setting up the correlation panels. Financial support for the study was provided by Fortum Petroleum AS. We thank Torgeir Vinje (then at Fortum Petroleum) for initiating and supporting the project. TNO Built Environment and Geosciences, Geological Survey of the Netherlands is acknowledged for access to the Holocene tidal basin data. The authors are grateful to NJG reviewers Poppe de Boer and Djin Nio for their constructive comments. 
Fig. 14. Plan view reconstruction of the spatial distribution of tidal channel sand bodies in the model area, based on the correlation of CPT cross sections.

\section{References}

Archer, A.W. \& Johnson, T.W., 1997. Modelling of cyclic tidal rhythmites (Carboniferous of Indiana and Kansas, Precambrian of Utah, USA) as a basis for reconstruction of inter-tidal positioning and palaeotidal regimes. Sedimentology 44: 991-1010.

Banerjee, I., 1977. Experimental study on the effect of deceleration on the vertical sequence of sedimentary structures in silty sediments. Journal of sedimentary Petrology 47: 771-783.

Beets, D.J., De Groot, Th.A.M. \& Davies, H.A., 2003. Holocene tidal backbarrier development at decelerating sea-level rise: a 5 millennia record, exposed in the western Netherlands. Sedimentary Geology 158: 117-144.

Beets, D.J., Roep, Th.B \& Westerhoff, W.E., 1996. The Holocene Bergen Inlet: closing history and related barrier progradation. Mededelingen Rijks Geologische Dienst N.S. 57: 97-131.

Beets, D.J. \& Van der Spek, A.J.F., 2000. The Holocene evolution of the barrier and the back-barrier basins of Belgium and the Netherlands as a function of late Weichselian morphology, relative sea-level rise and sediment supply. Netherlands Journal of Geosciences 79: 3-16.

Choi, K.S., Dalrymple, R.G., Chun, S.S. \& Kim, S.P., 2004. Sedimentology of modern inclined heterolithic stratification (IHS) in the macrotidal Han River Delta, Korea. Journal of sedimentary Research 74: 677-689.

Cleveringa, J. \& Oost, A.P., 1999. The fractal geometry of tidal-channel systems in the Dutch Wadden Sea. Geologie en Mijnbouw 78: 21-30.

Collinson, J.D. \& Thompson, D.B., 1982. Sedimentary Structures. George Allen \& Unwin (London): $194 \mathrm{p}$.

De Mulder, E.F.J. \& Bosch, J.H.A., 1982. Holocene stratigraphy, radiocarbon datings and paleogeography of central and northern North-Holland (the Netherlands). Mededelingen Rijks Geologische Dienst 36: 113-160.
Donselaar, M.E., Dalman, R.A.F., Dreyer, T., Petersen, S.A., Thomassen, R.A.J.

\& Toxopeus, G., 2006. Reservoir Architecture Modeling of the Cook Formation, Oseberg Field, Offshore Norway: Integrated Analysis of Core, Well Log and Seismic Data. AAPG 2006 Annual Meeting, Houston, Texas, April 9-12, 2006.

Donselaar, M.E. \& Geel, C.R., 2003. Reservoir architecture model for heterolithic tidal deposits. 65rd EAGE Conference \& Technical Exhibition - Stavanger, Norway, 2 - 5 June 2003.

Dreyer, T., 1992. Significance of tidal cyclicity for modelling of reservoir heterogeneities in the lower Jurassic Tilje Formation, mid-Norwegian shelf. Norsk Geol. Tidsskrift 72: 159-170.

Ente, P.J., 1971. Sedimentary geology of the Holocene in Lake IJssel region. Geologie en Mijnbouw 50: 373-382.

Geel, C.R. \& Donselaar, M.E., 2007. Reservoir modelling of heterolithic tidal deposits: sensitivity analysis of an object-based stochastic model. Netherlands Journal of Geosciences 86/4: 403-411.

Jelgersma, S., 1979. Sea-level changes in the North Sea basin. In: Oele, E., Schüttenhelm, R.T.E., Wiggers, A.J. (eds): The Quaternary History of the North Sea. Acta Univ. Upsala Symp. Annum Quingentesimum Celebrantis 2: 233-248.

Kapsimalis, V., Massé, L. \& Tastet, J.P., 2004. Tidal impact on modern sedimentary facies in the Gironde Estuary, southwestern France. Journal of Coastal Research SI41: 1-11.

Lunne, T., Robertson, P.K., \& Powell, J.J.M., 1997. Cone penetration testing in geotechnical practice. Blackie Academic \& Professional, London: 312p.

Martinius, A.W., Ringrose, P.S., Brostrøm, C., Elfenbein, C., Næss, A. \& Ringås, J.E., 2005. Reservoir challenges of heterolithic tidal sandstone reservoirs in the Halten Terrace, mid-Norway. Petroleum Geoscience 11: 3-16.

Nio, S.D. \& Yang, C.S., 1991. Diagnostic attributes of clastic tidal deposits: a review. In: Smith, D.G., Reinson, G.E., Zaitlin, B.A., Rahmani, R.A. (eds): Clastic Tidal Sedimentology. Can. Soc. Petrol. Geol. Mem., 16: 3-27. 


\section{Netherlands Journal of Geosciences - Geologie en Mijnbouw}

\section{Scope}

Netherlands Journal of Geosciences / Geologie en Mijnbouw seeks to be the prime outlet for publication of geo-scientific papers pertaining to the Netherlands and the North Sea region and relevant adjacent areas. Manuscripts on any geoscientific topic will be considered for publication, provided they comply with the regional focus of the journal and are of international interest and quality.

\section{Submission of manuscripts}

Manuscripts may be submitted to the Editorial Office. Manuscripts should be prepared in accordance with the instructions to authors' as summarized in every first issue of a volume; the instruction is also available upon request from the Editorial 0ffice and on the journal's website (www.njgonline.nl). The author(s) of manuscripts submitted are responsible for obtaining clearance for publication from relevant parties including, if appropriate, permission to include copyright material.

\section{Subscription and distribution}

Netherlands Journal of Geosciences / Geologie en Mijnbouw is published quarterly and dispatched by surface post. The journal is distributed to members of the Royal Geological and Mining Society of the Netherlands (KNGMG) free of charge and to private and institutional subscribers. The rate for institutional subscribers for the year 2007 is EUR 298, an individual subscription is EUR 80. Subscriptions are handled by Drukkerij Giethoorn ten Brink, Mrs. Mirjam R.H. Worst, P.0. Box 41, 7940 AA Meppel, the Netherlands (tel. +31 522855 175; fax +31 522855 176; email: m.worst@gmgroep.nl).

All orders (including requests for back issues) and related business correspondence (including address changes for subscribers) should be addressed to Drukkerij Giethoorn Ten Brink.

\section{Abstracting and indexing}

Netherlands Journal of Geosciences / Geologie en Mijnbouw is indexed/abstracted in Biological Abstracts, Current Contents/ Physical, Current Geographical Publications, Chemical \& Earth Sciences, Geological Abstracts, GeoArchive \& GeoTitles, Science Citation Index Expanded, ASCA, Cambridge Scientific Abstracts, INSPEC Information Services Petroleum Abstracts, Bibliography and Index of Geology, GeoRef, Geobase/ GeoAbstracts, Chemical Abstracts, The ISI Alerting Services.

\section{Access to NJG's internet version}

The Netherlands Journal of Geosciences is also published online (http://www.njgonline.nl). Access to the full texts of the articles is permitted only to subscribers (including all members of KNGMG). For individual subscribers the registration procedure is as follows: (1) Go to http://www.njgonline.nl; (2) Click on the button 'register' (top right); (3) Fill in the dialog box (surname and postal code as on the adress label of NJG) and finish with <send>; (4) You will receive your userid and password by email. To view articles in full text: (5) Go to http://www.njgonline.nl, using te button 'previous issue' (upper right-hand corner) you can then visit older issues; (6) To the right of each article title you find links to abstract and to full text; (7) Click on full text; (8) Log in by entering your userid and password in the dialog box. You can then view the selected article.

Institutional subscribers wishing to arrange automatic acces for the computers within their institutions should mail the appropriate IP adresses (or IP range) to m.c.p.adriaanse@library.uu.nl.

\section{Copyright and photocopying}

- Stichting Netherlands Joumal of Geosciences.

The journal (ISSN 0016-7746) is registered with the Copyright Clearance Center (CCC), 222 Rosewood Drive, Danvers, MA 01923, USA. Authorization to photocopy items for internal or personal use is granted by the Stichting Netherlands Journal of Geosciences, provided that the appropriate fee is paid directly to CCC. Prior to photocopying, please get permission online at the CCC wbsite (http://www.copyright.com) or call the CCC (+1 9787508400$)$, which can also be contacted for information about additional usage of material.

Requests for permission to reproduce material published in this journal for other publications should be addressed to the Editorial Office. 